\footnotetext{
${ }^{1}$ Department of Sheep and Goat Breeding, Agricultural University of Poznań, Poland

${ }^{2}$ Department of Sheep and Goat Breeding, Agricultural University of Lublin, Poland

${ }^{3}$ Research Institute of Animal Production, Prague - Uhrineves, Czech Republic
}

JACEK WÓJTOWSKI ${ }^{1}$, PIOTR ŚLÓSARZ ${ }^{1}$, ANDRZEJ JUNKUSZEW ${ }^{2}$, MICHAL MILERSKI $^{3}$, ANNA SZYMANOWSKA ${ }^{2}$ and MAREK SZYMANOWSKI ${ }^{2}$

\title{
Application of ultrasound technique for cistern size measurement in dairy goats (short communication)
}

\author{
Dedicated to Prof. Dr. Dr. h.c. Gerhard von Lengerken on the occasion of \\ his $70^{\text {th }}$ birthday
}

\begin{abstract}
The aim of the study was to compare ultrasound measurements of the gland cistern in goats obtained by various methods. The tests were conducted on goats of the Polish White Improved breed. Four ultrasound devices were used in the experiment, which were equipped with 4 different types of probes. The most similar measurements, $\mathrm{r}_{\mathrm{p}}$ from .729 to .927 , were obtained with the use of a SonoVet2000 with a linear probe with the frequency of 5 $\mathrm{MHz}$, applied to the middle part of the udder base, penetrating the opposite udder half and a Hitachi EUB 405+ with a $5.0 \mathrm{MHz}$ convex probe applied to the middle part of the base of the diagnosed udder half, directing the emission surface of the probe towards the teat.
\end{abstract}

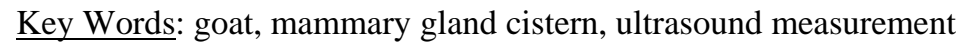

Zusammenfassung

Titel der Arbeit: Eignung der Ultraschalltechnik zur Messung von Euterzisternen bei Milchziegen (Kurzmitteilung)

Das Ziel der Untersuchung war der Vergleich unterschiedlicher Ultraschalltechniken zur Messung der Milchzisterne. Bei Ziegen der Rasse Polnische veredelte Weiße kamen vier verschiedene Ultraschallgeräte und Messköpfe zur Anwendung. Die größte Übereinstimmung von $r_{p}$ 0,729 bis 0,927 wurde zwischen den Methoden 1 und 4 erreicht. Die Methode 1 beinhaltet das SonoVet2000-Gerät mit einem 5 MHz linearen Schallkopf der am mittleren Teil des Euteransatzes angelegt wird wobei die Schallwellen die gegenüberliegende Euterhälfte durchdringen. Bei Methode 4 kommt das Ultraschallgerät Hitachi EUB 405+ mit einem 5 MHz konvexen Schallkopf zur Anwendung welcher am mittleren Teil des Euteransatzes der zu diagnostizierenden Euterhälfte in Richtung zur Zitze angelegt wird.

Schlüsselwörter: Ziege, Euterzisterne, Ultraschallmessung

\section{Introduction}

Milk yield is dependent on genetic and non-genetic factors, especially e.g. feeding, age, season of kidding, management conditions, milking technique, body weight or the structure of the udder. Studies on the relationships between udder measurements and milk yields in sheep and goats are scarce and concern primarily investigations using traditional tools such as measuring staffs, compasses and tapes (NARAIN et al., 1986; MAVROGENIS et al., 1989; FAHR et al., 2001b). Such measurements were usually taken on the exterior circumference of the udder, not taking into account individual variability in the thickness of the connective and adipose tissues surrounding the gland 
cistern, which considerably limited the accuracy of the measurement (MONTALDO and MARTINEZ-LOZANA, 1993; MIKUS, 1987; SCHULZ et al., 2004).

Along with the development of the ultrasound measurement technique it became possible to apply it to measure the dimensions of the gland cistern in small ruminants, including the assessment of the size of the gland cistern and thus - to forecast milk yield (RUBERTE et al., 1994). The first scientific studies conducted on small ruminants suggest the suitability of ultrasonography in this respect, although the measurement result was significantly affected by the site of probe application, as well as probe type and operating frequency (CAJA et al., 1999; ŚLÓSARZ et al., 2002; WÓJTOWSKI et al., 2002).

The aim of this study was to compare the results obtained using 4 ultrasound methods to measure the dimensions of the gland cistern section in milk goats.

\section{Materials and methods}

Experiments were conducted in April 2005 at the Bezek Experimental Station, belonging to the Agricultural University of Lublin (South-Eastern Poland) during the Polish - Czech Ultrasonography Training Meeting. Animal material consisted of 15 goats of the Polish White Improved breed aged 3 and 4 years, in the period after weaning, on average in week 8 of lactation. The mean milk yield of the analyzed goats was approx. 2.51 milk. Animals were kept in the indoor keeping system, with access to outside runs and were fed according to the feeding standards for milk goats in the first stage of lactation. Ultrasound diagnostics of the udder was performed at the milking stalls, twice in successive days, each time around noon approx. $6 \mathrm{~h}$ after the morning milking. Four ultrasound devices were used for the tests in case of each goat - the devices were equipped with 4 different types of probes, which each time determined the applied technique of udder measurement:

Method 1. A SonoVet2000 device with a linear probe with the frequency of $5 \mathrm{MHz}$ and operating width of $170 \mathrm{~mm}$. The probe was applied from the side of the animal (flank) to the middle part of the udder base at the angle of approx. 45\% penetrating the opposite udder half.

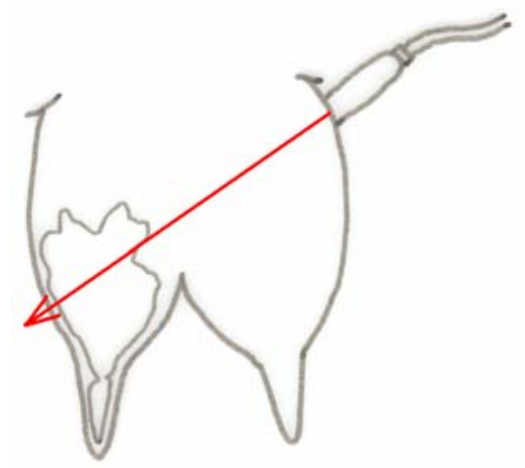

Fig. 1: Application of the probe during measurement taken using method 1 (Ansatz der Sonde bei Messung nach Methode 1)

Method 2. An EchoSon device with a section probe $\left(90^{\circ}\right)$ with the frequency of 5.0 $\mathrm{MHz}$. It was applied from the side of the rump in the middle of the Medial lamella dividing both halves of the udder, directing the emission surface of the probe towards the diagnosed udder half so that the teat could be seen in the background of the image. 


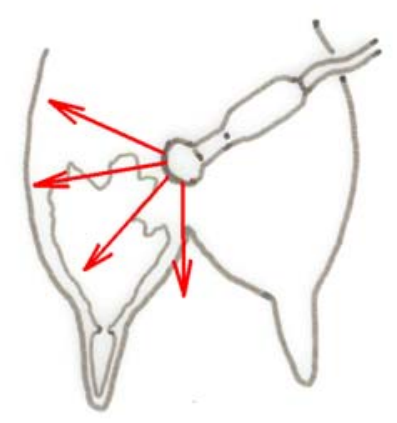

Fig. 2: Application of the probe during measurement taken using method 2 (Ansatz der Sonde bei Messung nach Methode 2)

Method 3. An ALOKA SSD 210 DXII with a $3.5 \mathrm{MHz}$ linear probe with the operating width $105 \mathrm{~mm}$. The probe was applied caudally to the tested udder half, so that the margin of the emission surface of the probe was in the site where the gland cistern changes into the teat canal.

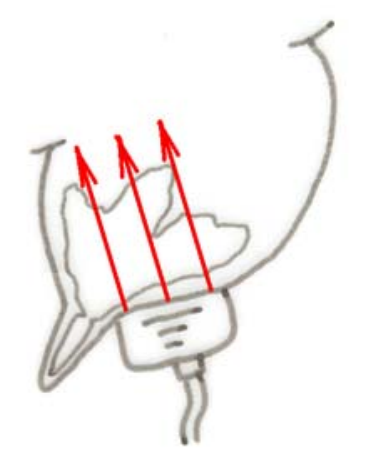

Fig. 3: Application of the probe during measurement taken using method 3 (Ansatz der Sonde bei Messung nach Methode 3)

Method 4. A Hitachi EUB 405+ device with a 5.0 MHz convex probe (R40). It was applied from the side of the rump of the animal to the middle part of the base of the diagnosed udder half, directing the emission surface of the probe towards the teat.

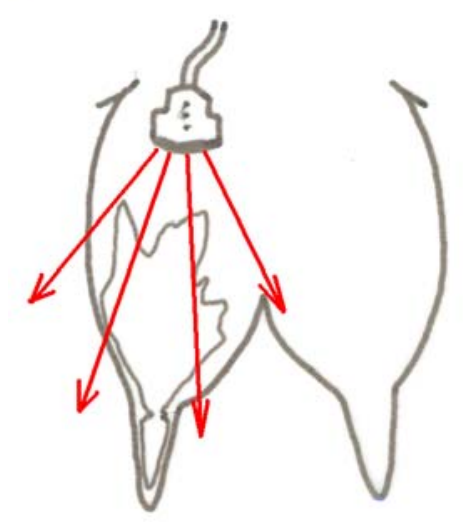

Fig. 4: Application of the probe during measurement taken using method 4 (Ansatz der Sonde bei Messung nach Methode 4)

Ultrasound testing using each device was performed by an individual qualified to operate the device and trained in udder diagnostics with the use of a given method. 
Ultrasound images were transmitted via an INDEO $^{\circledR}$ Fast Frame Grabber card to a computer and recorded in the form of disc files (a bit map). Measurements of the section area of the gland cistern of the udder were taken on the previously recorded ultrasound images using MULTISCAN ${ }^{\circledR}$ ver. 8.08 (1999) software. Both the ultrasound tests and image measurements were performed by the same individuals.

Statistical analysis of results taking into consideration the effect of the mesurement method and replications of the experiment on the section area of the gland cistern of both udder halves was performed using a two-way analysis of variance ANOVA $\left(S A S^{\circledR}\right.$, ver. 6.12.). Phenotypic correlations between measurement results obtained using different methods and correlations between successive replications of the experiment were calculated using the CORR statistical package SAS ${ }^{\circledR}$ ver. 6.12 (1996).

\section{Results}

Basic descriptive statistics of the size of the gland cistern in the tested goats are presented in Table 1. For both udder halves and in both replications of the experiment a similar coefficient of variation in the analyzed trait was found, ranging from 36 to $39 \%$. Mean results of measurements for each udder half in both replications of the experiment were also similar.

Table 1

Descriptive statistics of udder measurements taken using 4 methods (Beschreibung der Messdaten der vier angewandten Methoden)

\begin{tabular}{ccccccc}
\hline Udder half & Replication & $\mathrm{n}$ & $\begin{array}{c}\text { Size of } \\
\text { gland cistern } \\
{\left[\mathrm{cm}^{2}\right]}\end{array}$ & Min. & Max. & V\% \\
\hline Left & 1 & 60 & 35.00 & 4.48 & 62.86 & 38.59 \\
Left & 2 & 60 & 36.08 & 4.53 & 66.08 & 38.32 \\
Right & 1 & 60 & 38.27 & 13.28 & 69.09 & 36.40 \\
Right & 2 & 60 & 38.91 & 12.28 & 79.01 & 38.91 \\
\hline
\end{tabular}

Table 2

Area of gland cistern of udder depending on measurement method (Fläche der Milchdrüsenzisterne abhängig von der Messmethode)

\begin{tabular}{cccccc}
\hline Method $^{1}$ & $\mathrm{n}$ & $\begin{array}{c}\text { Left udder half } \\
1^{\text {st }} \text { replication } \\
\text { LSM } \pm \text { SE } \\
{\left[\mathrm{cm}^{2}\right]}\end{array}$ & $\begin{array}{c}\text { Left udder half } \\
2^{\text {nd }} \text { replication } \\
\text { LSM } \pm \text { SE } \\
{\left[\mathrm{cm}^{2}\right]}\end{array}$ & $\begin{array}{c}\text { Right udder half } \\
1^{\text {st }} \text { replication } \\
\text { LSM } \pm S E \\
{\left[\mathrm{~cm}^{2}\right]}\end{array}$ & $\begin{array}{c}\text { Right udder half } \\
2^{\text {nd }} \text { replication } \\
\text { LSM } \pm S E \\
{\left[\mathrm{~cm}^{2}\right]}\end{array}$ \\
\hline 1 & 15 & $37.21 \pm 3.21 \mathrm{a}$ & $38.03 \pm 3.46$ & $43.82 \pm 3.31 \mathrm{~A}$ & $42.94 \pm 3.66 \mathrm{a}$ \\
2 & 15 & $42.89 \pm 3.21 \mathrm{Ab}$ & $42.01 \pm 3.46 \mathrm{a}$ & $44.04 \pm 3.31 \mathrm{~B}$ & $46.26 \pm 3.66 \mathrm{~A}$ \\
3 & 15 & $26.56 \pm 3.21 \mathrm{Aa}$ & $29.80 \pm 3.46 \mathrm{a}$ & $29.49 \pm 3.31 \mathrm{AB}$ & $30.39 \pm 3.66 \mathrm{Aa}$ \\
4 & 15 & $33.34 \pm 3.21 \mathrm{~b}$ & $34.46 \pm 3.46$ & $35.71 \pm 3.31$ & $36.04 \pm 3.66$ \\
\hline
\end{tabular}

For both udder halves and in both replications the smallest section area of the gland cistern was found during the examination using method 3. Probably the probe with the width of $107 \mathrm{~mm}$ applied in such a way did not cover with its range the whole gland cistern. Additionally, the pressure of the probe onto the udder wall may to a certain extent deform the shape of the cistern - especially in case of the round form of the udder. However, high repeatability was found for measurements taken using this method, expressed as a correlation between the first and the second replication of the 
experiment (Table 4). Such a result suggests suitability of this method to test udders with moderate dimensions and those with a more elongated rather than round shape.

Table 3

Coefficients of correlation between measurements taken using individual methods (Korrelationskoeffizienten zwischen den Messwerten bei unterschiedlichen Methoden)

\begin{tabular}{lcccccc}
\hline Udder half/ & & \multicolumn{5}{c}{ Method } \\
replication & 1 vs. 2 & 1 vs. 3 & 1 vs. 4 & 2 vs. 3 & 2 vs. 4 & 3 vs. 4 \\
\hline Left/1 & $.673^{*}$ & $.729^{*}$ & $.927^{* *}$ & .542 & .556 & $.740^{* *}$ \\
Left/2 & $.741^{* *}$ & .551 & $.812^{* *}$ & .444 & $.782^{* *}$ & $.817^{* *}$ \\
Right/ 1 & $.727^{*}$ & $.626^{*}$ & $.893^{* *}$ & .431 & $.674^{*}$ & $.810^{* *}$ \\
Right/2 & $.683^{*}$ & .355 & $.729^{*}$ & $.707^{*}$ & $.825^{* *}$ & $.754^{* *}$ \\
\hline * - P $<0.01 ; * *-\mathrm{P}<0.001$ & & \multicolumn{6}{l}{}
\end{tabular}

Table 4

Correlation between the first and second replication of the experiment for each measurement method (Korrelationskoeffizienten zwischen den Messwiederholungen innerhalb der Methoden)

\begin{tabular}{lcccc}
\hline Udder & \multicolumn{4}{c}{ Method } \\
half & 1 & 2 & 3 & 4 \\
\hline Left & $.756^{* *}$ & $.606^{*}$ & $.907^{* *}$ & $.979^{* *}$ \\
Right & $.826^{* *}$ & $.867^{* *}$ & $.938^{* *}$ & $.975^{* *}$ \\
\hline *- P $\leq 0.01 ; * *-\mathrm{P} \leq 0.001$ & & &
\end{tabular}

The most similar measurement results of the section area of gland cisterns were obtained using methods 1 and 4. Only during the first replication of the left udder measurement the recorded images differed significantly ( $\mathrm{P} \leq 0.05$, Table 2). High consistency of results of both these methods is confirmed by the calculated phenotypic correlations $\left(0.729 \leq r_{p} \leq 0.927\right)$, usually the highest for a given udder half and experiment replications among the compared measurement methods. Each time the biggest section area of the gland cistern were obtained suing the section probe (method 2; Table 2). However, relatively low repeatability of the obtained results, especially for the left udder half, may limit its practical applicability (Table 4).

\section{Discussion}

Scientific papers on the application of ultrasound devices in the diagnostics of the udder in farm animals, especially in case of the udder in goats, so far have been scarce. In available scientific literature on the subject no results were found comparing the applied measurement methods in case of the animal udder with the use of ultrasound devices. In the study by FAHR et al. (2001a) determining the effect of the teat opening diameter on the hygienic quality of goat milk, the thickness of the connective tissue measured at the base of the teat sphincter muscle in the goat ranged from 4.22 to 5.56 $\mathrm{mm}$. The authors mentioned above obtained this measurement using a linear probe with the frequency of $10 \mathrm{MHz}$. CAJA et al. (1999) while diagnosing udders in 4-year old Ripollesa sheep with the use of a $5 \mathrm{MHz}$ section probe found a high interdependence of the width and section area of gland cisterns with milk production of ewes, amounting to $r_{p}=.81$ and $r_{p}=.90$, respectively. Phenotypic correlations defined in the same experiment between milk yield and the depth and width of the udder estimated using conventional methods, were only .34 and .38, respectively (CAJA et al., 1999). In turn, ŚLÓSARZ et al. 2002, while measuring the section area of the gland cistern of the udder in sheep from a synthetic milk line with a convex probe $(5 \mathrm{MHz})$, determined the level of correlation with their milk yields at $r_{\mathrm{p}}=.74$. An 
identical level was also found for a dependence between the above mentioned traits in Murciano-Granadina goats, determined using a $5 \mathrm{MHz}$ section probe in a study by SALAMA et al. (2004).

A higher level of interdependence between milk production and the area of the udder gland cistern than those given in the above mentioned studies, and amounting to $\mathrm{r}_{\mathrm{p}}=.86$, was reported by WÓJTOWSKI et al. (2002) in Polish White Improved goats. In the cited study the measuring devices and method were identical to those in method 3 used in the investigations presented in this study.

The conducted experiment shows that the most similar and relatively highly repeatable results were obtained using measuring methods no. 1 and 4. For practical reasons, in terms of the advisability of the site of probe application the best method seems to be especially method 1, ensuring (at a large operating width of the probe) full penetration of the opposite udder half and limiting the possible deformation of shape of the examined udder. Thus, further development of the udder diagnostic methods seems advisable, including ultrasound examinations of the udder immersed in water, minimizing the possible deformation of the examined mammary gland (MILERSKI et al., 2005).

\section{Acknowledgements}

The research was supported by grant 3 P06Z 02525 from the Polish State Committee for Scientific Research and project no. MZE0002701401 by the Ministry of Agriculture of the Czech Republic.

\section{References}

CAJA, G.; SUCH, X.; RUBERTE, J.; CARRETERO, A.; NAVARRO, M.:

The use of ultrasonography in the study of mammary gland cistern during lactation in sheep. Wageningen Pers. EAAP Publication No 95, (1999), 91-93

FAHR, R.-D.; SCHULZ, J.; RÖSNER, F.:

Melkbedingte Veränderungen an der Zitzenspitze der Ziege. Tierärztliche Praxis, 29 (G), (2001a), 151162

FAHR, R.-D.; SÜSS, R.; SCHULZ, J.; LENGERKEN, G. v.:

Vergleichende Untersuchungen zu Einflussfaktoren auf die somatische Zellzahl bei Schaf und Ziege. Arch. Tierz., Dummerstorf 44 (2001b) Special Issue, 288-298

MAVROGENIS, A.P.; PAPACHRISTOFORU, C.; LYSANDRIES, P.; RAUSHIAS, A.:

Environmental and genetic effect on udder characteristics and milk production in Damascus goats. Small Ruminant Research, 2, (1989), 333-334

MIKUS, M.:

Mutual relationship between udder dimensions and the relationship of udder dimension to the milk production in goat flocks with higher concentration. 38 EAAP-Meeting, Lisabon, (1987)

MILERSKI, M.; MARGETIN, M.; APOLEN, D.; CAPISTRAK, A.; SPANIK, J.:

Udder cistern size and milkability of ewes of various genotypes. ICAR Technical Series, 10, (2005), 6369

MONTALDO, H.; MARTINEZ-LOZANA, F. J.:

Phenotypic relationship between udder and milking characteristics, milk production and California

MULTISCAN $^{\circledR}$ : mastitis test in goats. Small Ruminant Research, 3, (1993), 329-337

MulitScanBase v. 8.08. User’s guide. Computer Scanning Systems, Ltd. (1999), Warsaw, PL.

NARAIN, S.; PRAKASH, B.; SIGH, B.:

Udder and teat dimensions of Janunapari goats at different stages of lactation. Indian Journal of Dairy Science, 3, (1986), 325-327

RUBERTE, J.; CARRETERO, A.; FERNANDEZ, M.; NAVARRO, M.; CAJA, G.; KIRCHER, F.; SUCH, X.: Ultrasound mammography in the lactating ewe and its correspondence to anatomical section. Small Ruminant Research, 13 (1994), 199-204 
SAS $^{\circledR}:$

SAS User's Guide Relase 6.12 (1996), Statistics. SAS Institute Inc. Cary, N.C., USA

SALAMA, A.A.K.; CAJA, G.; SUCH, X.; PERIS, S.; KNIGHT, C.H.:

Changes in cisternal udder compartment induced by milking interval in dairy goats milked once or twice daily. J. Dairy Sci. 87 (2004), 1181-1187.

SCHULZ, J.; SÜSS, R.; FAHR, R.-D.:

Beziehungen zwischen Euterformmerkmalen und Kriterien der Eutergesundheit bei Ostfriesischen Milchschafen. Arch. Tierz., Dummerstorf 47 (2004) Special Issue, 81-89

ŚLÓSARZ, P.; WÓJTOWSKI, J.; GUT, A.; JELIŃSKA, M.; GIZE M.:

Preliminary results of application of ultrasound technique for estimation of milk yield in the sheep. (in Polish with English summary). Zesz. Nauk. Przegl. Hod., 63, (2002), 113-118

WÓJTOWSKI, J.; ŚLÓSARZ, P.; GÓRECKI M.; MALECHA W.:

Ultrasound measurements of goat's mammary gland cisterns during lactation. (in Polish with English summary). Medycyna Wet., 58 (2002) 12, 977-980

Received: 2005-12-16

Accepted: 2006-05-03

Author's addresses

Prof. Dr. habil. JACEK WÓJTOWSKI*

Dr. habil. PIOTR ŚLÓSARZ

Department of Sheep and Goats Breeding

Agricultural University of Poznań

Złotniki, Słoneczna 1 Str.

62-002 SUCHY LAS, POLAND

*Corresponding author, E-Mail: jacwoj@neostrada.pl

Dr. MICHAL MILERSKI

Research Institute of Animal Production, Uhrineves

P.O.Box 1

10401 PRAGUE 10

CZECH REPUBLIC

Dr. ANDRZEJ JUNKUSZEW

Dr. ANNA SZYMANOWSKA

Dr. MAREK SZYMANOWSKI

Department of Sheep and Goats Breeding

Agricultural University of Lublin

Akademicka 13

0-950 LUBLIN, POLAND 